\title{
Methodology for cadastral valuation of agricultural lands occupied by water bodies
}

\author{
Kirill Zhichkin ${ }^{1}$, Vladimir Nosov ${ }^{2, *}$, Lyudmila Zhichkina ${ }^{1}$, Mira Alborova ${ }^{2}$, and Aleksey \\ Kuraev $^{2}$ \\ ${ }^{1}$ Samara State Agrarian University, 2 Uchebnaja str., 446442, Kinel, Russia \\ ${ }^{2}$ K.G. Razumovsky Moscow State University of Technologies and Management, 73, Zemlyanoy val, \\ 109004, Moscow, Russia
}

\begin{abstract}
The article considers features of cadastral valuation of agricultural lands occupied by water bodies. The research is based on natural water bodies of the Samara region water fund. A methodology for determining the cadastral value of agricultural lands occupied by artificial water bodies is proposed. The methodology links the land value with the size of the land plot, profit and such objects as dams and other hydraulic structures located within the land plot. The paper confirmed the suggestion that the owner of the land that shall be used for the construction of a pond has the right to the added value of land in the amount of return rate of contributed capital $(26.28 \%)$. The cadastral value of 1 square meter of agricultural land is 3.11 rubles.
\end{abstract}

\section{Introduction}

The fourth type of permitted use of land plots includes agricultural lands occupied by water bodies and used for entrepreneurial activity $[1,2]$. Water bodies refer to artificial ponds and impoundments [3]. Natural water bodies refer to the water fund of the Samara region.

In the rural real estate market, only ponds and impoundments that can be used for fish and game farming are traded. These objects are already stocked when sold and have supporting infrastructure. These objects should be considered with respect to business, which contradicts to the purposes of the assessment because business is associated with additional investments not related to the initial acquisition of land and dam construction [4-8].

The cost of these objects ranges from 20 to 50 rubles per square meter of the water surface.

Serviced lands adjacent to water bodies or villages and located $30-40 \mathrm{~km}$ from the city cost even more, considering that they can be used for the construction of houses or recreation centres. The cost of these lands ranges from 50 rubles to 200-250 rubles per square meter. In a case such as this not only a land plot is being sold but also a possibility of housing development and reclassification of land. This speculative (subjective) markup should be excluded from the calculations, which is hard to do [9-14].

\footnotetext{
*Corresponding author: novla@list.ru
} 


\section{Methods and Materials}

The procedure for calculating the value of land plots of the fourth type of permitted use is similar to the procedure for calculating the value of land plots of the third type of permitted use (lands occupied by manufacturing facilities), however, in this case, the land value is not influenced by the distance factor and population in the municipal district [5, 15-17].

Selling land for construction of a pond or an impoundment, the owner can claim a part of the profit that emerges from the synergistic effect by adding the land to improvements (in this case - dams). Equitable distribution of profit from the joint use of assets can be estimated based on the contribution to the joint affair [18-20]. This proposition can be confirmed by the calculation of the value of a typical fish pond.

\section{Results and Discussion}

When calculating the dam value, it must be taken into account that carp pond dams are usually earthen dams. They are constructed across the river bed, ravines, draws or flood lands. Impoundments and the majority of finishing ponds are constructed by damming the river bed of a small river or a stream, ravine, draw, or a hollow in the narrowest yet suitable for construction place. The impoundment dam is the largest and most expensive construction of the pond fish culture.

The width of the dam crest (the upper part) should be at least 1-2 meters; if the dam is meant for traffic, it should be 3.5 meters in width and more. The dam should be $0.5-1$ meters higher than the flood level, and for impoundments - 1.5-2 meters higher.

The toe of the upstream slope is usually twice or three times larger than its height. The toe of the downstream is usually only 1.5-2 times higher.

The most common type of dam construction is a contour dam. The cross-sectional area of this dam can be calculated given the depth of the pond of 2 meters at the dam [1]. The average depth of finishing ponds should be 1.3-2.2 meters. Hence given the following geometrical parameters:

- dam height - 3.5 meters

- dam crest width - 3.5 meters,

- dam thickness - 20 meters,

the sectional area of the dam body will be approximately 41 square meters. 4

The size of the dam (width, length) depends on the required volume of water and the backwater effect.

Table 1. Water bodies of the Samara region.

\begin{tabular}{|l|l|c|c|c|c|}
\hline № & \multicolumn{1}{|c|}{ Location } & $\begin{array}{c}\text { Water-surface area, } \\
\text { square meters } \\
\text { (approximately) }\end{array}$ & $\begin{array}{c}\text { Dam } \\
\text { length, } \\
\text { meters }\end{array}$ & $\begin{array}{c}\text { Dam length } \\
\text { to pond area } \\
\text { ratio }\end{array}$ & $\begin{array}{c}\text { Pond area to } \\
\text { dam length } \\
\text { ratio }\end{array}$ \\
\hline 1 & $\begin{array}{l}\text { Bolsheglushitsky District, 6.5 } \\
\text { km to the east of Moksha }\end{array}$ & 900000 & 540 & 0.0006 & 1667 \\
\hline 2 & $\begin{array}{l}\text { Bolsheglushitsky District, 4.5 } \\
\text { km to the south-east of Malaya } \\
\text { Glushitsa (63:14:0705003:52) }\end{array}$ & 56765 & 280 & 0.004932617 & 203 \\
\hline 3 & $\begin{array}{l}\text { Bolsheglushitsky District, ravin } \\
\text { Yagodniy }\end{array}$ & 212280 & 260 & 0.001224797 & 816 \\
\hline 4 & $\begin{array}{l}\text { Bolsheglushitsky District, 5.5 } \\
\text { km to the north of Malaya } \\
\text { Glushitsa (1 pond) } \\
\text { (63:14:0301002:24) }\end{array}$ & 298010 & 300 & 0.001006678 & 993 \\
\hline
\end{tabular}




\begin{tabular}{|c|c|c|c|c|c|}
\hline 5 & $\begin{array}{l}\text { The Samara region, } \\
\text { Bolsheglushitsky District, } 8750 \\
\text { meters to the north-east of } \\
\text { Konstantinovka } \\
(63: 14: 0301002: 23)\end{array}$ & 46506 & 250 & 0.00537565 & 186 \\
\hline 6 & $\begin{array}{l}\text { Bolsheglushitsky District, } 2.5 \\
\mathrm{~km} \text { to the south-east of Karalyk } \\
(63: 14: 0609001: 28)\end{array}$ & 1480000 & 740 & 0.0005 & 2000 \\
\hline 7 & $\begin{array}{l}\text { Koshkinsky District, } \\
\text { Srednepravaya Chesnokovka }\end{array}$ & 193800 & 350 & 0.001805986 & 554 \\
\hline 8 & Kinelsky District, Alakaevka & 75200 & 230 & 0.003058511 & 327 \\
\hline 9 & $\begin{array}{l}\text { Krasnoarmeysky District, } 1.8 \\
\text { km to the north-east of. } \\
\text { Sophinsky }(63: 25: 0605016: 23)\end{array}$ & 365253 & 330 & 0.000903483 & 1107 \\
\hline 10 & $\begin{array}{l}\text { Krasnoarmeysky District, } \\
\text { (63:25:1005002:0012) }\end{array}$ & 101205 & 108 & 0.001067141 & 937 \\
\hline & Average & & & 0.002047 & 879 \\
\hline
\end{tabular}

Using the map of the Samara region, we determined the sizes of dams ( \pm 10 meters) and the water-surface area ( \pm 100 square meters) of several ponds with a typical elongated shape. A part of the objects was identified through the use of an accurate public cadastral map. The results of the measurements are presented in table 1.

To calculate the unit cost of construction of the dam, we used the replacement cost aggregates. According to table 2, the total cost of construction of 1 cubic meter of a dam in the Samara region is 442 rubles including VAT.

Table 2. Initial data for calculation of construction costs.

\begin{tabular}{|l|c|}
\hline \multicolumn{1}{|c|}{ Object of estimation } & \multicolumn{1}{|c|}{ Pond dam } \\
\hline Unit of measurement & 1.0 \\
\hline Main parameter, units & 2011 \\
\hline Year of construction & Compendium №37, table 7b \\
\hline $\begin{array}{l}\text { The number of the compendium of replacement cost aggregates } \\
\text { and the table }\end{array}$ & $\begin{array}{l}\text { Earthen dams built by means of } \\
\text { hydraulicking, odd jobs, } \\
\text { excavation and transportation. }\end{array}$ \\
\hline $\begin{array}{l}\text { Characteristics of the analogue from the compendium of } \\
\text { replacement cost aggregates }\end{array}$ & 3.00 \\
\hline Replacement cost according to the compendium, rubles/units & 1.00 \\
\hline Correction factor for a climatic region & 1.00 \\
\hline Correction factor for durability & 1.00 \\
\hline Correction factor for structural volume & 3.00 \\
\hline Other corrections & 3.0 \\
\hline $\begin{array}{l}\text { The adjusted value of an aggregate, rubles/cubic meters in prices } \\
\text { of 1969 }\end{array}$ & 3.60 \\
\hline $\begin{array}{l}\text { The adjusted value of an aggregate, rubles/cubic meters in prices } \\
\text { of 1984 (Decree of the State Committee for Construction of } \\
11.05 .1983, \text { ratio - 1.2) }\end{array}$ & 5.76 \\
\hline $\begin{array}{l}\text { The adjusted value of an aggregate, rubles/cubic meters in prices } \\
\text { of 1991 (Letter of the State Committee for Construction of } \\
\text { 06.09.1990 № 14-D, ratio - 1.6) }\end{array}$ & 63.687 \\
\hline $\begin{array}{l}\text { Construction and installation works index (1991-the date of } \\
\text { estimation) (Index of increase in costs of construction and } \\
\text { installation works at the date of the estimation. The data is } \\
\text { obtained from the Center for Pricing in Construction) }\end{array}$ & 366.8 \\
\hline An aggregate in current prices, rubles/measurement unit & 367 \\
\hline Total per object of estimation, rubles & \\
\hline
\end{tabular}


Total per object of estimation in terms of $2 \%$ unforeseen costs, rubles

\begin{tabular}{|l|l|}
\hline 374 \\
\hline 442 \\
\hline
\end{tabular}
Total per object of estimation, incty
excluding wear and tear), rubles

With the specific indicator of dam construction cost, we can calculate the dam construction cost in our sample, as shown in table 3.

We can determine the size of the synergistic effect and the potential profit of the landowner by taking the value of occupied land as 1.5 rubles/square meters. We also calculated the potential profit of the owner using the construction return rate of $26.28 \%$ [ 21 23].

Table 3. Cost of dam construction for chosen water bodies of the Samara region.

\begin{tabular}{|c|l|c|c|}
\hline № & \multicolumn{1}{|c|}{ Location } & $\begin{array}{c}\text { Dam volume, } \\
\text { cubic meters }\end{array}$ & $\begin{array}{c}\text { Cost of dam } \\
\text { construction, } \\
\text { thousand rubles }\end{array}$ \\
\hline 1 & Bolsheglushitsky District, 6.5 km to the east of Moksha & 41980 & 18535.4 \\
\hline 2 & $\begin{array}{l}\text { Bolsheglushitsky District, 4.5 km to the south-east of } \\
\text { Malaya Glushitsa (63:14:0705003:52) }\end{array}$ & 2648 & 1169.1 \\
\hline 3 & Bolsheglushitsky District, ravin Yagodniy & 9902 & 4371.9 \\
\hline 4 & $\begin{array}{l}\text { Bolsheglushitsky District, 5.5 km to the north of Malaya } \\
\text { Glushitsa (63:14:0301002:24) }\end{array}$ & 13901 & 6137.5 \\
\hline 5 & $\begin{array}{l}\text { The Samara riong, Bolsheglushitsky District, 8.7 km to } \\
\text { the north-east of Konstantinovka (63:14:0301002:23) }\end{array}$ & 2169 & 957.8 \\
\hline 6 & $\begin{array}{l}\text { Bolsheglushitsky District, 2.5 km to the south-east of } \\
\text { Karalyk (63:14:0609001:28) }\end{array}$ & 69034 & 30480.4 \\
\hline 7 & Koshkinsky District, Srednepravaya Chesnokovka & 9040 & 3991.3 \\
\hline 8 & Kinelsky District, Alakaevka & 3508 & 1548.7 \\
\hline 9 & $\begin{array}{l}\text { Krasnoarmeysky District, 1.8 km to the north-east of. } \\
\text { Sophinsky (63:25:0605016:23) }\end{array}$ & 17037 & 7522.3 \\
\hline 10 & Krasnoarmeysky District (63:25:1005002:0012) & 4721 & 2084.3 \\
\hline
\end{tabular}

Hence, the value of the improved land plot is identified as the sum of the land plot value calculated based on the value of surrounding land and the additional cost arising from the synergistic effect of investments into property. Therefore, we confirmed the assumption that the owner of the land that shall be used for the construction of a pond has the right to the added value of land in the amount of return rate of contributed capital, which is $26.28 \%$.

Table 4. Calculation of land owner's profit and market value of the land occupied by pond.

\begin{tabular}{|c|c|c|c|c|c|c|}
\hline № & Location & $\begin{array}{c}\text { Value of } \\
\text { the land } \\
\text { plot } \\
\text { occupied } \\
\text { by a pond, } \\
\text { thousand } \\
\text { rubles }\end{array}$ & $\begin{array}{c}\text { Total cost of } \\
\text { construction } \\
\text { of a water } \\
\text { body, } \\
\text { thousand } \\
\text { rubles }\end{array}$ & $\begin{array}{c}\text { Potential } \\
\text { profit of } \\
\text { investor, } \\
\text { thousand } \\
\text { rubles }\end{array}$ & $\begin{array}{c}\text { Land } \\
\text { owner's } \\
\text { profit } \\
\text { share, } \\
\text { thousand } \\
\text { rubles }\end{array}$ & $\begin{array}{l}\text { Market } \\
\text { value of the } \\
\text { land plot } \\
\text { occupied by } \\
\text { a pond, } \\
\text { rubles }\end{array}$ \\
\hline 1 & $\begin{array}{l}\text { Bolsheglushitsky District, } \\
6.5 \mathrm{~km} \text { to the east of } \\
\text { Moksha }\end{array}$ & 1350.0 & 19885.4 & 5225.9 & 354.8 & 1.89 \\
\hline 2 & $\begin{array}{l}\text { Bolsheglushitsky District, } \\
4.5 \mathrm{~km} \text { to the south-east } \\
\text { of Malaya Glushitsa } \\
(63: 14: 0705003: 52)\end{array}$ & 85.1 & 1254.2 & 329.6 & 22.4 & 1.89 \\
\hline 3 & $\begin{array}{l}\text { Bolsheglushitsky District, } \\
\text { ravin Yagodniy }\end{array}$ & 318.4 & 4690.3 & 1232.6 & 83.7 & 1.89 \\
\hline
\end{tabular}




\begin{tabular}{|c|c|c|c|c|c|c|}
\hline 4 & $\begin{array}{l}\text { Bolsheglushitsky District, } \\
5.5 \mathrm{~km} \text { to the north of } \\
\text { Malaya Glushitsa (1 } \\
\text { pond) -63:14:0301002:24 }\end{array}$ & 447.0 & 6584.5 & 1730.4 & 117.5 & 1.89 \\
\hline 5 & $\begin{array}{l}\text { Bolsheglushitsky District, } \\
8.7 \mathrm{~km} \text { to the north-east } \\
\text { of Konstantinovka } \\
(63: 14: 0301002: 23)\end{array}$ & 69.8 & 1027.5 & 270.0 & 18.3 & 1.89 \\
\hline 6 & $\begin{array}{l}\text { Bolsheglushitsky District, } \\
2.5 \mathrm{~km} \text { to the south-east } \\
\text { of Karalyk } \\
(63: 14: 0609001: 28)\end{array}$ & 2220.0 & 32700.4 & 8593.7 & 583.4 & 1.89 \\
\hline 7 & $\begin{array}{l}\text { Koshkinsky District, } \\
\text { Srednepravaya } \\
\text { Chesnokovka }\end{array}$ & 290.7 & 4282.0 & 1125.3 & 76.4 & 1.89 \\
\hline 8 & $\begin{array}{l}\text { Kinelsky District, } \\
\text { Alakaevka }\end{array}$ & 112.8 & 1661.5 & 436.6 & 29.6 & 1.89 \\
\hline 9 & $\begin{array}{l}\text { Krasnoarmeysky District, } \\
1.8 \text { km to the north-east } \\
\text { of. Sophinsky } \\
(63: 25: 0605016: 23)\end{array}$ & 547.9 & 8070.2 & 2120.8 & 144.0 & 1.89 \\
\hline 10 & $\begin{array}{l}\text { Krasnoarmeysky District, } \\
\text { plot 63:25:1005002:0012 }\end{array}$ & 151.8 & 2236.1 & 587.6 & 40.0 & 1.89 \\
\hline
\end{tabular}

The share of land in the total value of the object - 0.0679;

The share of the landowner's profit, rubles/square meter -0.39 .

The equation for the value of land occupied by a water body used for fish farming is as follows:

$$
C_{\text {wat. }}=C_{\text {surr. }} \cdot 1.2628
$$

Table 5. Determination of the cadastral value of land occupied by water bodies of the Bezenchugsky

District of the Samara region.

\begin{tabular}{|l|c|c|c|c|c|c|}
\hline $\begin{array}{c}\text { Number of the } \\
\text { land plot }\end{array}$ & $\begin{array}{c}\text { Permitted } \\
\text { use }\end{array}$ & $\begin{array}{c}\text { Area, } \\
\text { square } \\
\text { meters }\end{array}$ & $\begin{array}{c}\text { Unit } \\
\text { cadastral } \\
\text { value of a } \\
\text { vacant land } \\
\text { plot, } \\
\text { rubles/square } \\
\text { meters }\end{array}$ & $\begin{array}{c}\text { Unterprenuer's } \\
\text { profit, \% }\end{array}$ & $\begin{array}{c}\text { Unit } \\
\text { cadastral } \\
\text { value of land } \\
\text { occupied by a } \\
\text { water body, } \\
\text { rubles/square } \\
\text { meters }\end{array}$ & $\begin{array}{c}\text { Cadastral } \\
\text { value of } \\
\text { the land } \\
\text { plot, } \\
\text { rubles }\end{array}$ \\
\hline $\begin{array}{l}\text { 63:12:0708005: } \\
13\end{array}$ & For pond & 574 & 2.46 & 26.28 & 3.11 & 1783.12 \\
\hline $\begin{array}{l}63: 12: 0708005: \\
14\end{array}$ & For pond & 1020 & 2.46 & 26.28 & 3.11 & 3168.62 \\
\hline $\begin{array}{l}63: 12: 0708005: \\
15\end{array}$ & For pond & 339 & 2.46 & 26.28 & 3.11 & 1053.10 \\
\hline $\begin{array}{l}63: 12: 0708006: \\
4\end{array}$ & For pond & 12764 & 2.46 & 26.28 & 3.11 & 39651.21 \\
\hline $\begin{array}{l}63: 12: 0708006: \\
88\end{array}$ & For pond & 341068 & 2.46 & 26.28 & 3.11 & 1059523.65 \\
\hline
\end{tabular}

According to table 4, the market (cadastral) value of the surrounding land can be obtained from the results of the valuation of lands of the first type of permitted use. The unit cadastral value is chosen for the evaluated land plot. Usually, it is chernozem soil under the fishing pond, which is very fertile and contributes to the productivity of the pond. Table 5 contains 
the calculations of the cadastral value of lands occupied by water bodies for several districts of the region.

\section{Conclusion}

The proposed methodology links the land value with the objects located within the land plot (dams and other hydraulic structures). In addition, the evaluation uses the cadastral value and size of the adjacent land plot and the entrepreneur's profit. The unit cadastral value of 1 square meter of agricultural lands is 3.11 rubles.

\section{References}

1. E.A. Staselko, O.V. Erdinev, T.A. Balinova, U.S. Germasheva, S.A. Snadjieva, A.V. Baryshev, IOP Conference Series: Materials Science and Engineering 663, 012050 (2019) doi: 10.1088/1757-899X/663/1/012050

2. K. Zhichkin, V. Nosov, L. Zhichkina, V. Zhenzebir, O. Sagina, IOP Conference Series: Earth and Environmental Science 421, 022066 (2020) doi: 10.1088/1755$1315 / 421 / 2 / 022066$

3. E. Bykowa, J. Sishchuk, ZFV - Zeitschrift fur Geodasie, Geoinformation und Landmanagement 140, 22-26 (2015)

4. T. Cay, M. Uyan, Land Use Policy 30, 541-548 (2013) doi: 10.1016/j.landusepol.2012.04.023

5. C.E. Boyd, J.R. Bowman, Dynamics of Pond Agriculture, 135-162 (2017) doi: 10.1201/9780203759028

6. M. Ottinger, K. Clauss, C. Kuenzer, Ocean and Coastal Management 119, 244-266 (2016) doi: 10.1016/j.ocecoaman.2015.10.015

7. C. Béné, R. Arthur, H. Norbury, E.H. Allison, M. Beveridge, S. Bush, L. Campling, M. Williams, World Development 79, 177-196 (2016) doi: 10.1016/j.worlddev.2015.11.007

8. S. Ma, S.M. Swinton, Ecological Economics 70, 1649-1659 (2011) doi: 10.1016/j.ecolecon.2011.04.004

9. P. Sklenicka, K. Molnarova, K.C. Pixova, M.E. Salek, Land Use Policy 30, 130-136 (2013) doi: 10.1016/j.landusepol.2012.03.005

10. D. Demetriou, Land Use Policy 54, 487-498 (2016) doi: 10.1016/j.landusepol.2016.03.008

11. T. Mcclanahan, E.H. Allison, J.E. Cinner, Fish and Fisheries 16, 78-103 (2015) doi: 10.1111/faf.12045

12. O.V. Mamai, I.N. Mamai, M.V. Kitaeva, Digital Age: Chances, Challenges and Future 84, 359-365 (2020)

13. K.A. Zhichkin, V.V. Nosov, V.I. Andreev, O.K. Kotar, L.N. Zhichkina, IOP Conference Series: Earth and Environmental Science 341, 012005 (2019) doi:10.1088/17551315/341/1/012005

14. A. Tyutyunikov, A. Pashuta, T. Zakshevskaya, IOP Conference Series: Earth and Environmental Science 274, 012012 (2019) doi: 10.1088/1755-1315/274/1/012012

15. J. Kilić, K. Rogulj, N. Jajac, Croatian Operational Research Review 10, 89-103 (2019) doi: 10.17535/crorr.2019.0009

16. A. Borchers, J. Ifft, T. Kuethe, American Journal of Agricultural Economics 96, 13071320 (2014) doi: 10.1093/ajae/aau041 
17. B.A. Delbecq, Y.H. Kuethe, A.M. Borchers, Land Economics 90, 587-600 (2014) doi: 10.3368/le.90.4.587

18. M.K. Awasthi, Land Use Policy 39, 78-83 (2014) doi: 10.1016/j.landusepol.2014.04.002

19. T.V. Yalyalieva, V.V. Nosov, T.S. Volkova, M.T. Tekueva, I.V. Pavlenko, Research Journal of Pharmaceutical, Biological and Chemical Sciences 6, 1620-1624 (2016)

20. J. Choumert, P. Phélinas, Ecological Economics 110, 134-140 (2015) doi: 10.1016/j.ecolecon.2014.12.024

21. A. Itemgenova, M. Sikveland, Journal of Commodity Markets 17, 100089 (2020) doi: 10.1016/j.jcomm.2019.04.001

22. J. Kruse, M. Koch, C.M. Khoi, G. Braun, Z. Sebesvari, W. Amelung, Science of the Total Environment 703, 134758 (2020)

23. Y. Chang, W. Wang, X. Liu, F. Du, D. Yao, Polish Journal of Environmental Studies 29, 571-577 (2020) doi: 10.15244/pjoes/102373

24. A. Poltarykhin, V. Nosov, L. Poletaeva, V. Avdotin, V. Grishin M. Babakisiyev, Journal of Environmental Management and Tourism 3, 508-514 (2019) doi:10.14505//jemt.v10.3(35).05 